DISCIPLINE AND THE OTHER BODY 



\title{
Discipline
}

\section{and the Other Body}

\author{
$*$ \\ Correction, Corporeality, Colonialism \\ edited by \\ STEVEN PIERCE \& ANUPAMA RAO
}

Duke University Press Durham and London 2006 
(C) 2006 Duke University Press

\author{
All rights reserved \\ Printed in the United States of America \\ on acid-free paper $\infty$ \\ Designed by C. H. Westmoreland
}

Typeset in Minion by Keystone Typesetting, Inc.

Library of Congress Cataloging-in-Publication Data

appear on the last printed page of this book. 